\title{
Towards Entrepreneurial Learning Competencies: The Perspective of Built Environment Students
}

\author{
Kissi Ernest ${ }^{1}$, Somiah K. Matthew ${ }^{2}$ \& Ansah K. Samuel ${ }^{3}$ \\ ${ }^{1}$ Department of Building Technology, Kwame University of Science and Technology, Kumasi, Ghana \\ ${ }^{2}$ Department of Building Technology, Takoradi Polytechnic, Takoradi, Ghana \\ ${ }^{3}$ Department of Building Technology, Cape Coast Polytechnic, Cape Coast, Ghana \\ Correspondence: Kissi Ernest, Department of Building Technology, Kwame University of Science and \\ Technology, Kumasi, Ghana. E-mail: kisernest@yahoo.com
}

Received: October 20, 2014

Accepted: December 20, 2014 Online Published: January 21, 2015

doi:10.5539/hes.v5n1p20

URL: http://dx.doi.org/10.5539/hes.v5n1p20

\begin{abstract}
This paper sought to discuss entrepreneurial learning competencies by determining the outcome of entrepreneurial learning on the views of built environment students in the university setting. In this study, three relevant competencies were identified for entrepreneurial learning through literature, namely: entrepreneurial attitude, entrepreneurial skills and knowledge of entrepreneurship. On this basis, questionnaire was designed and administered to graduate students in built environment. In all, a total of 124 questionnaires were administered to respondents. Out this, 84 were retrieved representing a response rate of $68 \%$ and were further subjected to analysis using Relative Importance Index (RII). The findings from the study highlighted on competencies factors that have great impact on entrepreneurs in dealing with tasks and problems related to entrepreneurial learning processes. These key entrepreneurial competencies as perceived by the built environment students were ranked as: entrepreneurial attitude, knowledge of entrepreneurship and entrepreneurial skill. The findings may help stakeholders in the building industry including up-coming graduate students. Thus, it could help in their journey into entrepreneurial terrain affiliated to advancement of their career, as a way to increase private wealth and the pursuit of a more balanced life.
\end{abstract}

Keywords: entrepreneurial, learning, built environment students, competencies

\section{Introduction}

Entrepreneurship is now considered as a major contributor to global economic growth (McStay, 2008). Entrepreneurship as an academic discipline is still considered as relatively new although its origin can be traced back to the seventeenth century, when economist Richard Cantillon (Ibid) coined the term, "entrepreneur". The literal definition of this French term (entrepreneur) is "to undertake" or "go between" referring to the position an individual assume when pursuing an opportunity. Since the introduction of entrepreneurship education by the United States in the 1940s, the concept has been adopted and integrated into education in many countries as a component of new economic strategy for fostering job creation (McMullan et al., 2001). It has become such an important part of education. UNESCO World Conference (1998), recognized the value of entrepreneurship and advocated for cultivating entrepreneurship and skills in higher education.

Until recently, just about a decade ago, entrepreneurship as a course was not taught at all in most tertiary institutions in Ghana (Adjimah, 2011) although, there are now a lot of activities that point out to an increased interest and recognition in entrepreneurship education. According to Unemployed Graduates Association of Ghana (UGAG, 2012), an average of 70,000 graduates from the country's tertiary institutions come out of school searching for jobs annually. They further report that, over 88,000 graduates nationwide are unemployed, which makes about 50.8 percent of graduates from the universities, polytechnics and other tertiary institutions. Bello (2010) argues that the increasing rate of graduate unemployment is a prevalent problem in virtually all parts of the world. Governments are not able to provide employment opportunities for the large number of graduates who stream out of the universities annually. Job vacancies are practically non-existent. No one is left out, whether a first class, an average or the dim-witted student.

Amoako (2010) opines that Ghana's educational structure since independence has continued to be predicated on 
the colonial style of education. Thus, the focus of educationist have not been to train people who can innovate, create, invent and more importantly employ themselves, instead of relying on government or someone else to employ them. The approach adopted in teaching the vast array of courses in our institutions of higher education leaves much to be desired. Students study for the purposes of examinations and it virtually ends there. The consequence of this approach to teaching and learning has produced graduates who lack analytical and innovative thinking which is much needed in the job market.

According to Marques and Albuquerque (2012), an entrepreneurial mind-set and entrepreneurial skills like creativity, pro-activity, risk aversion, tolerance for ambiguity, ability to foresight, can be important characteristics for employees who are not entrepreneurs: they can be successfully exploited also in non-entrepreneurial contexts, by improving the performance and the employability of the skilled person. It is clear that the right type of entrepreneurship education has the propensity of increasing graduates' chances of employment and as such the impact of entrepreneurial learning on the built environment students should be explored. Hence, the aim of this study was to determine the relative importance of entrepreneurial learning competencies from the perspective of built environment students.

\subsection{Entrepreneurship Education}

Cooney and Murray (2008), suggested that internationally, entrepreneurship or enterprise based modules are increasingly being incorporated into non-business courses; more significantly, interest and demand in these modules is growing among science, engineering, and arts faculties. It is no longer enough to come out of school with a purely technical education. Professionals need to be entrepreneurial in order to understand and contribute in the context of market and business pressures. Students with entrepreneurial training who join established firms are better prepared to become effective team members and managers and can better support their employers as innovators. Entrepreneurship education teaches "engineering" students in all disciplines, the knowledge, tools, and attitudes that are required to identify opportunities and bring them to life. Students who take part in entrepreneurship programs as undergraduates gain insights not available from traditional education, such as understanding and designing for end users ("empathy"), working in and managing interdisciplinary teams, communicating effectively, thinking critically, understanding business basics, and solving open-ended problems (NAE, 2004). At higher education level, the primary purpose of entrepreneurial education should be to develop entrepreneurial capacities and mind-sets. Entrepreneurship education should not be confused with general business and economic studies, as its goal is to promote creativity, innovation and self-employment. Entrepreneurial programmes offer the student the tools to think creatively, to be an effective problem solver, to communicate, to network and to lead. The aim of entrepreneurship education is to teach students the attitude, skills and information that are needed later on in working life regardless of whether one works for someone else or as an independent entrepreneur. Entrepreneurial learning on all levels has three main objectives:

- Raising learners' awareness of self-employment as a career option;

- Promoting the development of personal qualities that are relevant to entrepreneurship, such as creativity, risk-taking and responsibility; and

- Providing the technical and business skills that are needed in order to start and run a new business.

It is a well-established fact across the world that entrepreneurship courses have positive impact on the employability of graduates on society and the economy (Owusu-Ansah \& Poku, 2012). Consequently, in several advanced countries, entrepreneurship education is offered right from the primary school level through to secondary school and to the tertiary level of education (Blenker et al., 2011). In Nigeria for instance, entrepreneurship is a mandatory course for students of Higher Education Institutions (HEIs) (Omoniyi \& Osakinle, 2011).

In Ghana, however, same cannot be said. Entrepreneurship education seems to be pursued, largely, in Higher Education Institutions (HEIs) with a number of polytechnics, professional institutes and universities offering one or few entrepreneurship courses and/or programmes. In a bid to solving the graduate unemployment canker in Ghana in recent times and in response to government's call to tertiary institution to help find solutions to graduate unemployment, a number of tertiary institutions in Ghana including Universities and Polytechnics are offering entrepreneurship as a module in their curricula to create awareness and recommend self-employment as an alternative and a better lucrative career path. Kwame Nkrumah University of Science and Technology (KNUST), Kumasi, for instance is now running entrepreneurship development programme with Business Incubator and Enterprise Centres (Adarkwa, 2010). It is interesting to note that, no one knows the impact that these initiatives are having on unemployment as there are no statistics on graduate business start-ups; and the graduate unemployment queue continues to get longer and longer (see Fosu \& Boateng, 2013). According to 
Owusu-Ansah and Poku (2012), entrepreneurship education at KNUST Business School is creating entrepreneurship awareness and encouraging students to include "self-employment in their career intentions and aspirations' options as well as inculcating a positive attitude towards business start-up". Undoubtedly, HEIs in Ghana have in place courses aimed at equipping students with some entrepreneurship related competencies. However, the design and delivery of these conventional courses appear to focus highly on content with less emphasis on role-oriented practice and lesser development of skills necessary for creativity and innovation (Mensah, 2013). Moreover, "traditional forms of teaching at universities and business schools have shown to be quite inappropriate with respect to enhancement of motivation and competencies among students towards innovation and entrepreneurship' (Blenker et al., 2006). A course carved within the subject discipline of entrepreneurship is expected to offer students the opportunity to develop holistic entrepreneurial behaviour and focuses more on supplementing knowledge acquisition with skill-building, attitudinal change and experiential learning.

\subsection{Entrepreneurial Competencies}

Over the last decade, competence-based education has received significant attention and is currently booming in several countries. It is often believed that competence is a combination of knowledge, skills and attitudes required by employees in the performance of their jobs or tasks (Stoof, 2005). Gibb (1990) defines it as "an ability to perform certain tasks for which knowledge, skills, attitudes and motivations are necessary". Sanchez (2011) also defines competencies as "a cluster of related knowledge, traits, attitudes and skills that affect a major part of one's job; that correlate with performance on the job; that can be measured against well-accepted standards; and that can be improved via training and development".

In spite of the relative differences in the definitions, the observation is that the term competence is a broad concept that consistently associates knowledge, skills, attitudes and motivations as dimensions that competent entrepreneurs must be able to use in order to deal with the tasks and problems related to their entrepreneurial actions (Onstenk, 2003). Thus, the combination of a positive attitude with the right knowledge and skills produces entrepreneurs with the necessary competencies to face challenges and uncertainties that are characteristic of business start-up and/or self-employment.

According to Garavan and O'Cinneide (1994), three major features of innovators and entrepreneurs are their knowledge, skills and attitudes. In most formal education situations, the first is treated thoroughly and in an analytical manner; the second receives sketchy attention and is more difficult to impart within formal educational systems; the third is hardly addressed. In this study, entrepreneurial competencies are defined as knowledge, skills and attitudes that affect the willingness and ability to perform the entrepreneurial job of new value creation; that can be measured directly or indirectly; and that can be improved through training and development. Research on entrepreneurial skills has been conducted for decades. For example, Langlois (2003) stated that successful entrepreneurs should be innovative, creative and risk-taking. This view later has been reinforced in follow-up studies, like that by Wickham (2006), which stated that entrepreneurs are creative, seek and discover niches for market innovations, bear risks, are growth-oriented, and are driven to maximise profit or investors' returns.

Successful entrepreneurs believe strongly in their ideas and enjoy sharing those ideas with others. Because they trust their own instincts, they can be very persuasive in swaying others to accept their ideas. Successful entrepreneurs are able to convince and inspire the required network members into reaching shared goals, i.e. they need to have both good networks and networking competence (Peters, 2005). Gürol and Atsan (2005) found out that entrepreneurially oriented students are found to have a higher risk taking propensity, an internal locus of control, a higher need for achievement and higher innovativeness than other students with no entrepreneurial desire. One key attribute associated with entrepreneurialism is change (Langlois, 2003). Entrepreneurs seem to have a high tolerance for ambiguity and changing situations in the environment in which they most often operate (Adaptability). This ability to handle uncertainty is critical because they are constantly making decisions using new, sometimes conflicting information obtained from numerous unfamiliar sources (Zimmerer \& Scarborough, 2002). Lazear (2005) has also shown that individuals with balanced and wide skill-sets are more likely to become entrepreneurs than those that are focused on one role at work or one subject at school.

Lambing and Kuehl (2000) outlined a number of requirements for entrepreneurs: tolerance of obstacles, perseverance, determination, risk management, a positive attitude towards change, tolerance of uncertainties, initiative, the need to achieve, punctuality, an understanding of timeframes, creativity and motivation. These requirements may form one of the basic differentiating factors between entrepreneurs and other people. A successful entrepreneur is both a creator and an implementer, someone who does not only dreams of new things, 
but is also willing to work hard in order to achieve them.

In summary, it is difficult to form an exact definition of what skills are required of an entrepreneur. However, the referenced studies agree that entrepreneurial competencies are often psychological or social skills, not skills specific to a business or an academic branch. Entrepreneurship education seeks to produce students who are entrepreneurial. An entrepreneurial person demonstrates three key entrepreneurial competencies. These are entrepreneurial knowledge, skills and attitudes (European Commission, 2012). These competencies manifest themselves in the individual in the form of innovation, change and action essential for personal, social and work life (Mensah, 2013). Three entrepreneurial competencies must therefore be embedded in every entrepreneurship course or programme of study. A summary of the entrepreneurship competencies that this study consider is presented in table 1 .

Table 1. The entrepreneurial competencies

\begin{tabular}{lll}
\hline Skills & Attitude & \multicolumn{1}{c}{ Knowledge } \\
\hline Creativity & Sense of Initiative & Understanding of entrepreneurship \\
Analysing & Risk-taking propensity & Role of entrepreneurs \\
Motivating & Self-efficacy & $\begin{array}{l}\text { Determinants of } \\
\text { entrepreneurship }\end{array}$ \\
& & \\
Networking & Need for achievement & \\
Adaptability & Structural behaviour & \\
Financial management & & \\
Source: European Commission $(2012)$ &
\end{tabular}

Source: European Commission (2012)

\section{Methodology}

This paper adopted the mixed method approach for data collection. At the first stage of the data collection process, qualitative approach was used to identify the relevant competencies needed for the learning of entrepreneurship among built environment students through a literature survey. The relevant competencies were based on the European Commission postulation. The second stage of the data collection process involved the use of questionnaires The respondents were given the questionnaires and were asked to rate the level of significance using a five-point scale ranging from scale $1-5$, where $1=$ very low, $2=$ low, $3=$ fair, $4=$ high and $5=$ very high. In all, 124 questionnaires were administered purposively to built environment students who are currently pursuing their masters' programme in area of Construction Management, Procurement Management, Building Technology, Architecture, Road and Transportation Engineering and Settlement Planning. Out of the 124 questionnaires administered, 84 were retrieved representing a response rate of $68 \%$. The sample was chosen based on the fact that graduate students are in a better position to give more credible responses to the questions due to their perceived exposure to industry and have gone through an entrepreneurial education during their first degree. Data generated from the survey was further analysed using Relative Importance Index (RII) for the ranking of the factors identified. The aim of the analysis was to establish the relative importance of the various factors. The relative importance index (RII) was calculated using the formula adopted by Fagbenle et al., (2004).

$$
\begin{aligned}
& R I I=\sum P i U i \\
& \quad N(n) \\
& \text { Where } R I I=\text { Relative Importance Index } \\
& P_{i}=\text { respondent rating of important } \\
& U_{i}=\text { respondent's placing identical weighting or rating on the important } \\
& N=\text { sample size } \\
& n=\text { the highest attainable score on the important }
\end{aligned}
$$

\section{Data Analysis}

Entrepreneurship key competencies have been outlined in Table 2 and figure 1(brainstorming) based on the analysis. The mean as well as the RII scores of all the eighty four (84) respondents were calculated for each competence and have been presented in Table 2. Respondents were asked to rate in their opinion how much 
confidence they had in their possession of these competencies. As shown in Table 2, the competencies have been categorised under three (3) separate headings namely: Entrepreneurial attitude which was ranked $1^{\text {st }}$ among the competencies with an average RII of 0.7686 , Knowledge of entrepreneurship came up $2^{\text {nd }}$ with an average RII of 0.7675 and Entrepreneurial skills being ranked $3^{\text {rd }}$ with an average RII of 0.7667 . From the results in Table 2, the need for achievement is the most significant Entrepreneurial attitude obtaining an RII of 0.8476 and a mean of 4.238, followed by Structural behaviour which was ranked $2^{\text {nd }}$ with an RII of 0.7905 and a mean of 3.952 . Risk-taking propensity ranked $5^{\text {th }}$ with an RII of 0.681 and a mean of 3.405 , confirming that the aversion to risk-taking is a challenge in entrepreneurship education in Ghana as shown in Table 2. With regards to Entrepreneurial skills, respondents had the highest confidence in Motivating skills with an RII of 0.8071 and a mean of 4.036. Analysing skills was ranked $2^{\text {nd }}$ with an RII of 0.7762 and a mean of 3.881. Networking skills was ranked $6^{\text {th }}$ with an RII of 0.7286 and a mean of 3.643. Lastly, with regards to Knowledge of Entrepreneurship, most respondents recorded high confidence in their understanding of entrepreneurship, which was ranked $1^{\text {st }}$ with an RII of 0.7833 and a mean of 3.917. Knowledge in the determinants of successful entrepreneurship came $2^{\text {nd }}$ while the role of entrepreneurs was ranked $3^{\text {rd }}$.

Table 2. Self-perception of the key entrepreneurship competencies by respondents

\begin{tabular}{|c|c|c|c|c|c|c|c|c|c|c|c|c|}
\hline \multirow{2}{*}{ COMPETENCIES } & \multicolumn{5}{|c|}{ FREQUENCY OF RANKING } & \multirow{2}{*}{ TOTAL } & \multirow{2}{*}{$\sum \boldsymbol{W}$} & \multirow{2}{*}{ MEAN } & \multirow{2}{*}{$R I I$} & \multirow{2}{*}{ RANKING } & \multirow{2}{*}{$\begin{array}{c}\text { AVERAGE } \\
\quad R I I\end{array}$} & \multirow{2}{*}{$\begin{array}{l}\text { OVERALL } \\
\text { RANKING }\end{array}$} \\
\hline & 1 & 2 & 3 & 4 & 5 & & & & & & & \\
\hline Entrepreneurial Attitude & & & & & & & & & & & 0.7686 & $1^{s t}$ \\
\hline Sense of initiative & & 2 & 25 & 47 & 10 & 84 & 317 & 3.774 & 0.7548 & $4^{\text {th }}$ & & \\
\hline Risk-taking propensity & & 7 & 41 & 31 & 5 & 84 & 286 & 3.405 & 0.681 & $5^{t h}$ & & \\
\hline Self-efficacy & & 5 & 18 & 46 & 15 & 84 & 323 & 3.845 & 0.769 & $3^{r d}$ & & \\
\hline Need for achievement & & 3 & 4 & 47 & 30 & 84 & 356 & 4.238 & 0.8476 & $1^{s t}$ & & \\
\hline Structural behaviour & & & 23 & 42 & 19 & 84 & 332 & 3.952 & 0.7905 & $2^{\text {nd }}$ & & \\
\hline Entrepreneurial Skills & & & & & & & & & & & 0.7667 & $3^{r d}$ \\
\hline Creativity & & 2 & 22 & 46 & 14 & 84 & 324 & 3.857 & 0.7714 & $4^{\text {th }}$ & & \\
\hline Analysing & & 2 & 19 & 50 & 13 & 84 & 326 & 3.881 & 0.7762 & $2^{\text {nd }}$ & & \\
\hline Motivating & & 2 & 17 & 41 & 24 & 84 & 339 & 4.036 & 0.8071 & $1^{s t}$ & & \\
\hline Networking & & 9 & 25 & 37 & 13 & 84 & 306 & 3.643 & 0.7286 & $6^{t h}$ & & \\
\hline Adaptability & & 2 & 25 & 39 & 18 & 84 & 325 & 3.869 & 0.7738 & $3^{r d}$ & & \\
\hline Financial management & & 8 & 28 & 28 & 20 & 84 & 312 & 3.714 & 0.7429 & $5^{\text {th }}$ & & \\
\hline Knowledge of Entrepreneurship & & & & & & & & & & & 0.7675 & $2^{\text {nd }}$ \\
\hline Understanding of entrepreneurship & & 3 & 20 & 42 & 19 & 84 & 329 & 3.917 & 0.7833 & $1^{s t}$ & & \\
\hline Role of entrepreneurs & 1 & 4 & 22 & 43 & 14 & 84 & 317 & 3.774 & 0.7548 & $3^{r d}$ & & \\
\hline $\begin{array}{l}\text { Determinants of successful } \\
\text { entrepreneurship }\end{array}$ & & 6 & 19 & 43 & 16 & 84 & 321 & 3.821 & 0.7643 & $2^{\text {nd }}$ & & \\
\hline
\end{tabular}




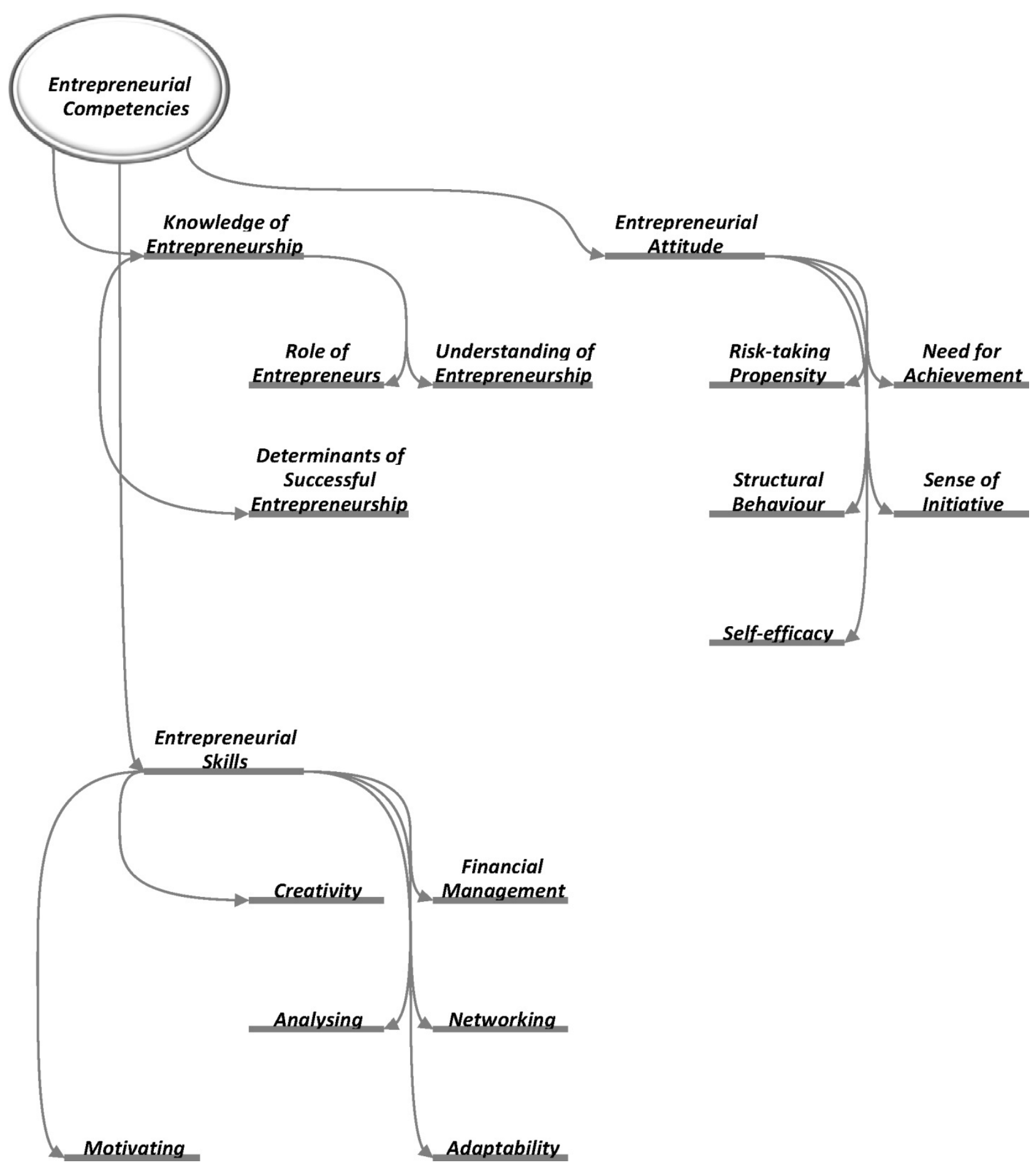

Figure 1. Key competencies of successful entrepreneurship [brainstorming diagram]

\section{Discussions}

\subsection{Entrepreneurial Attitude}

In past years, Hindle and ve Rushworth (2000) investigated into Global Entrepreneurship Monitor and came to a conclusion that, to supply welfare, economic growth, and to sustain development, countries must realize the intentions of citizens towards setting up their own businesses.

Available literature opines that, virtually, every field of life career such as performance, leadership, relationships, etc. as well as entrepreneurship is important to national development. The aim of entrepreneurship can be explained by a prime approach such as the idea of self-efficacy (Moen \& Allgood, 2009). Based on social 
cognitive theory, peoples' opinions about their capabilities to perform a particularly successful task take form via dynamic, continuous, and mutual activity between personal, behavioural, and environmental factors (Bandura, 2001). These opinions massively influence how much travail people put forth, how long they will persist against odds, how resilient they are in dealing with failures, and how much stress or anxiety they experience in coping with demanding situations (Henson, 2001). Consequently, the entrepreneurial intent does not only configure students' personalities but also configuring depending on the precedence aim of the dynamic circumstance of being according to their taste and prospect (Top et al., 2012). According to Top et al. (2012), delighting in a new job is specified as a deliberate pick impacted by self-interest of individuals.

As commonly defined, an entrepreneur is a person who takes the initiative of their future into their own hands and self-change or realizing themselves (Top, 2006). Thompson (2009) reveals that, in the individual consciousness, the idea of entrepreneurship is one of the prime issues in the prospect that people reckon to establish their own business on the beliefs of experimenting the formation of a new business. Granted the indispensable valence of self-efficacy on students' motivation, learning, and achievement (Pajares \& Urdan, 2006), entrepreneurship scholars applied self-efficacy to explain students' entrepreneurial behaviour, competence, and intention (Barbosa et al., 2007; Wilson et al., 2007; Segal et al., 2005). Entrepreneurs crave innovation and new opportunities and that these dispositions usher to constructive risk-taking (Miller, 2007). Considerably, the key variables that influence organizations' competitiveness are the psychological and behavioural characteristics together with management and field-specific (technical knowledge and skills) of entrepreneurs. The study confirmed the assertion by Moen and Allgood as entrepreneurial attitude was identified by all the respondents as the major key entrepreneurial competence.

\subsection{Knowledge of Entrepreneurship}

Certainly, acquiring knowledge is key for the improvement of each system. According to Rae (2005), entrepreneurial learning is undoubtedly toward acquiring knowledge from a new field or adding up to existing one. In addition, healthier understanding of entrepreneurship knowledge is essential for the creation of entrepreneurship education and training programmes so that we can discern the entrepreneur's learning needs via concentrating on the personal and business development of the entrepreneur (Rae \& Carswell, 2000). Usually, a factor that has been portrayed as having a significant impact on entrepreneurial success is the technical knowledge and "know-how" (Ahmad et al., 2014). As widely discussed, the different aims and objectives of entrepreneurship education include increasing the knowledge of participants, improving their entrepreneurial abilities and behaviour in life and providing them with the useful set of skills and competences for establishing a new start-up or managing an existing firm (Heinonen \& Hytti, 2010). Consequently, understanding these different objectives and applying them in the formation of entrepreneurship studies is regarded to be the key advancing effective programmes (Hynes, 1996; Hytti \& O'Gorman, 2004; Blenker et al., 2006). Nevertheless, the role of an entrepreneur can be successfully be drawn from the definition of an entrepreneur. According to Unachukwu (2009), an entrepreneur is a person (or group of persons) who initiates a business, organizes, controls and combines other factors of production, directs the processes of production and bears all the attendant risks. In the view of Arogundade (2011), an entrepreneur is a person who possesses the ability to recognize and evaluate business opportunities, assemble the necessary resources to take advantage of them and take appropriate action to succeed.

Knowledge of entrepreneurship was ranked second from the views of built environment students. This is not surprising because with the lack of knowledge, entrepreneurs will perish.

\subsection{Entrepreneurial Skills}

Generally, it is an absolute effect of the need to make ready graduates from diverse types of higher education institutions to run in rapidly dynamic social and economic conditions by arming them with knowledge and skills related to the operations of enterprises as well as managing individual businesses (Plaziak \& Rachwal, 2014). In parallel with intense research, tremendous research findings have been established on rendering various learning opportunities to advance entrepreneurial abilities with emphasis on entrepreneurial leadership competencies in students (Fayolle \& Gailly, 2008; Heinonen \& Poikkijoki, 2006; Okudan \& Rzasa, 2006; Zhao et al., 2005). As observed by Dehghani et al. (2014) via thriving learning, the skills, knowledge and abilities required in different stages of business development can be acquired so that they can be applied subsequently. Notwithstanding, entrepreneurial learning has been largely limited to learning entrepreneurship hypothetically and not more than managing pocket-sized simulated or proper businesses (Plumly et al., 2008; Fayolle et al., 2006; Zhao et al., 2005). Thus, entrepreneurship has been deemed to be self-employment (Bagheri, 2010). Meanwhile, there is an accord among entrepreneurship scholars that entrepreneurship is not just operating a small business that already 
exists (Man \& Yu, 2007; Fayolle et al., 2006; Heinonen \& Poikkijoki, 2006; Kuratko, 2005). Instead, it is a change management, creative thinking, opportunity seeking and innovativeness (Mattare, 2008; Fernald, et al., 2005). The availability of financial capital to support venture formation and growth has been proven a key contingency (Ahmad et al., 2014). Accordingly, to confront the difficulties of building and managing a company in its entirety, many scholars substantiate the need to recount engineering, economic and managerial skills (Mojab, 2011). The ability to learn is essential in developing entrepreneurial capabilities (Rae \& Carswell, 2000). The influence of human capital on entrepreneurial activities is apparent especially when the owners employ their knowledge and skills onto the new venture (Lafuente \& Rabetino, 2011). Available literature postulates that, in the setting of entrepreneurship, featuring a vast network and linkages would equip entrepreneurs to make up for the deficiency of other types of assets (Ferri et al., 2009). Consequently, during the professional lives of an entrepreneur, a web of handy contacts is often pulled together. During the gathering of useful contacts, DeBruin and Firkin (2001) in their research argues that a study that focuses on older entrepreneurs identified that both informal and formal networks are crucial for a new venture. The significance of networking towards entrepreneurial ventures has been highlighted by many scholars and this could offer evidence that such personal links can help entrepreneurs gain both finance and marketing support (Ahmad et al., 2014). Hence, the respondents' altogether perceived entrepreneurial skills which embeds creativity, analysing, motivating, networking, adaptability and financial management as the least ranked competence.

\section{Conclusion}

The entrepreneurial learning competencies were of prime importance in this paper. Consequently, the paper sought to investigate entrepreneurial leaning competencies among built environment students. The study identified entrepreneurial attitude, knowledge of entrepreneurship and entrepreneurial skills as the key competencies. It was also found that, entrepreneurship education and training makes a positive contribution to job creation and improving competitiveness and economic advancement throughout market economies.

It should be noted that entrepreneurial learning presents a medium for groom young graduates thereby according them with necessary attitude, knowledge and skills in discharging their professional duties. Hence, the need for evaluation and incorporating these key competencies in the educational process remain critical if any meaningful employability and job creation attitude are to be seen among young graduates.

It is therefore important that policy makers within the educational sector gives a particular attention to the training of built environment students for economic improvement by making an apprise decision about the entrepreneurial competencies identified. It also recommended that entrepreneurship teachings should be a dynamic mix of process and action focus.

\section{References}

Adarkwa, K. K. (2010). The End of a Season: End of Tenure Report as Vice Chancellor (2006-10). Kumasi, Ghana: University Press, KNUST.

Adjimah, H. (2011). Step by Step Guides to Setting up your Business: Entrepreneurship Development I. Accra: Excel Publications.

Arogundade, B. B. (2011). Entrepreneurship Education: An Imperative for Sustainable Development in Nigeria. Journal of Emerging Trends in Educational Research and Policy Studies (JETERAPS), 2(1), 26-29.

Ahmad, N. H., Nasurdin, A. M., Halim, H. A., \& Taghizadeh, S. K. (2014). The Pursuit of Entrepreneurial Initiatives at the "Silver" Age: From the Lens of Malaysian Silver Entrepreneurs. Procedia-Social and Behavioral Sciences, 129, 305-313. http://dx.doi.org/10.1016/j.sbspro.2014.03.681

Amoako, S. (2010). Graduate Unemployment in Ghana: The Myth. Retrieved October 3, 2013, from http://www.ghanaweb.com/GhanaHomePage/blogs/blog.article.php?blog=2335\&ID=1000005813

Bagheri, A., \& Pihie, Z. A. L. (2010). Entrepreneurial Leadership Learning: In Search of Missing Links. Procedia-Social and Behavioral Sciences, 7, 470-479. http://dx.doi.org/10.1016/j.sbspro.2010.10.064

Bandura, A. (2001) Social Cognitive Theory: An Agentic Perspective Annu. Rev. Psychol., 52, 1-26.

Barbosa, S. D., Gerhardt, M. W., \& Kickul, J. R. (2007). The Role of Cognitive Style and Risk Preference on Entrepreneurial Self-Efficacy and Entrepreneurial Intentions. Journal of Leadership and Organizational Studies, 13(4), 86-104. http://dx.doi.org/10.1177/10717919070130041001

Bello, D. A. (2010). Educated and Unemployed: The Dilemma of Graduates in Africa. Retrieved October 16, 2013, from http://futurechallenges.org/local/educated-and-unemployed-the-dilemma-of-graduates-in-south-africa 
Blenker, P., Dreisler, P., \& Kjeldsen, J. (2006), Entrepreneurship Education-The New Challenge Facing the Universities (p. 2). A Framework for Understanding and Development of Entrepreneurial University Communities, Working Paper 2006, Aarhus School of Business, Aarhus.

Blenker, P., Korsgaard, S., Neergaard, H., \& Thrane, C. (2011). The Questions we Care About: Paradigms and Progression in Entrepreneurship Education. Industry \& Higher Education, 25(6), 417-427. http://dx.doi.org/10.5367/ihe.2011.0065

Cooney, T., \& Murray, T. (2008). Entrepreneurship Education in the Third-Level Sector in Ireland. Institute of Minority Entrepreneurship Report, Dublin Institute of Technology.

DeBruin, A., \& Firkin, P. (2001). Self-Employment and the Older Worker. Massey University of New Zealand, Auckland.

Dehghani, S., Gharooni, A., \& Arabzadeh, A. (2014). Staff Empowerment, Entrepreneurial Behaviors and Organizational Efficiency in Iranian Headquarter Education. Procedia-Social and Behavioral Sciences, 109, 1130-1141. http://dx.doi.org/10.1016/j.sbspro.2013.12.600

European Commission, Enterprise and Industry Directorate-General. (2012). Effects and Impact of Entrepreneurship Programmes in Higher Education. Retrieved October 21, 2013, from http://ec.europa.eu/enterprise/policies/sme/promoting-entrepreneurship/files/education/effects_impact_high _edu_final_report_en.pdf

Fagbenle, O. I., Adeyemi, A. Y., \& Adesanya, D. A. (2004). The Impact of Non-Financial Incentive on Bricklayers' Productivity in Nigeria. Construction Management and Economics, 22, 899-911. http://dx.doi.org/10.1080/0144619042000241262

Fayolle, A., \& Gailly, B. (2008). From Craft To Science, Teaching Models and Learning Processes in Entrepreneurship Education. Journal of European Industrial Training, 32(7), 569-593. http://dx.doi.org/10.1108/03090590810899838

Fayolle, A., Gailly, B., \& Lassas-Clerc, N. (2006). Assessing the Impact of Entrepreneurship Education Programmes: A New Methodology. Journal of European Industrial Training, 30(9), 701-720. http://dx.doi.org/10.1108/03090590610715022

Fernald, L. W. Jr., Solomon, G. T., \& Tarabishy, A. (2005). A New Paradigm: Entrepreneurial Leadership. Southern Business Review, 30(2), 1-10.

Ferri, P.J., Deakins, D., \& Whittam, G. (2009). The Measurement of Social Capital in the Entrepreneurial Context. Journal of Enterprising Communities: People and Places in the Global Economy, 3(2), 138-151. http://dx.doi.org/10.1108/17506200910960842

Fosu, R., \& Boateng, R. E. (2013). The Scottish University Level Entrepreneurship Education Initiative: Lessons for Ghana in Dealing with Graduate Unemployment. Journal of Education and Practice, 4(24), 143-151.

Garavan, T. N., \& O'Cinneide, C. (1994). Entrepreneurship Education and Training Programmes: A Review and Evaluation-Part 1. Journal of European Industrial Training, 18(8), 3-12 http://dx.doi.org/101108/03090599410068024

Gibb, A. (1990). Training the Trainers of Small Business. Journal of European Industrial Training, 14, 17-25. http://dx.doi.org/10.1108/03090599010138543

Gürol, Y., \& Atsan, N. (2005). Entrepreneurial Characteristics amongst University Students: Some Insights for Entrepreneurship Education and Training in Turkey. Education and Training, 48(1), 25-38. http://dx.doi.org/10.1108/00400910610645716

Heinonen, J., \& Hytti, U. (2010). Back to Basics: The Role of Teaching in Developing the Entrepreneurial University. The International Journal of Entrepreneurship and Innovation, 11(4), 283-292. http://dx.doi.org/10.5367/ijei.2010.0006

Heinonen, J., \& Poikkijoki, S-A. (2006). An Entrepreneurial-Directed Approach to Entrepreneurship Education: Mission impossible? Journal of Management Development, 25(1), 80-94. http://dx.doi.org/10.1108/02621710610637981

Henson, R. K. (2001). Teacher Self-Efficacy: Substantive Implications and Measurement Dilemmas.

Hindle, K., \& ve Rushworth, S. (2000). Global Entrepreneurship Monitor Hawthorne. Victoria, Swinburne, Australia: University of Technology, Australia. 
Hynes, B. (1996). Entrepreneurship Education and Training - Introducing Entrepreneurship into Non-Business Disciplines. Journal of European Industrial Training, 20(8), 10-17. http://dx.doi.org/10.1108/03090599610128836

Hytti, U., \& O'Gorman, C. (2004). What is "Enterprise Education"? An Analysis of the Objectives and Methods of Enterprise Education Programmes in Four European Countries. Education and Training, 46(1), 11-23. http://dx.doi.org/10.1108/00400910410518188

Kuratko, D. F. (2005). The Emergence of Entrepreneurship Education: Development, Trends, and Challenges. Entrepreneurship Theory and Practice, 29(5), 577-597. http://dx.doi.org/10.1111/j.1540-6520.2005.00099.x

Lafuente, E., \& Rabetino, R. (2011). Human Capital and Growth in Romanian Small Firms. Journal of Small Business and Enterprise Development, 18(1), 74-96. http://dx.doi.org/10.1108/14626001111106442

Lambing, P., \& Kuehl, C. R. (2000). Entrepreneurship (2nd ed.). Englewood Cliffs, NJ: Prentice-Hall.

Langlois, R. N. (2003). Schumpeter and the Obsolescence of the Entrepreneur (Vol. 6, pp. 283-298). Emerald Group Publishing Limited.

Lazear, E. P. (2005). Entrepreneurship. Journal of Labour Economics, 23(4), 649-680. http://dx.doi.org/10.1086/491605

Man, T. W. Y., \& Yu, C. W. M. (2007). Social Interaction and Adolescent's Learning in Enterprise Education: An Empirical Study. Education + Training, 49(8/9), 620-633.

Marques, L. A., \& Albuquerque, C. (2012). Entrepreneurship Education and the Development of Young People Life Competencies and Skills. ACRN Journal of Entrepreneurship Perspectives, 1(2), 55-68.

Mattare, M. (2008). Teaching Entrepreneurship: The case for an entrepreneurial leadership course (pp. 78-93). USASBE Proceedings.

McMullan, W. E., Chrisman, J. J., \& Vesper, K. (2001). Some Problems in Using Subjective Measures of Effectiveness to Evaluate Entrepreneurial Assistance Programs. Entrepreneurship Theory and Practice, 26, (1), 37-54.

McStay, D. (2008). An Investigation of Undergraduate Student Self-Employment Intention and the Impact of Entrepreneurship Education and Previous Entrepreneurial Experience. Australia: School of Business, Bond University.

Mensah, M. S. B. (2013). Entrepreneurship Education on Wholesale? Considerations on Didactics and Pedagogy for Enhanced Graduate Employment in Ghana. European Journal of Business and Management, 5(15), 109-113.

Miller, K. (2007). Risk and Rationality in Entrepreneurial Processes. Strategic Ent. Journal, 1(1-2), 57-74.

Moen, F., \& Allgood, E., (2009). Coaching and the Effect on Self-efficacy. Organization Development Journal, 27(4), 69-83.

Mojab, F., Zaefarian, R., \& Azizi, A. H. D. (2011). Applying Competency Based Approach for Entrepreneurship $\begin{array}{llll}\text { Education. Procedia-Social and Behavioral } & \text { Sciences, }\end{array}$ http://dx.doi.org/10.1016/j.sbspro.2011.02.054

National Academy of Engineering (NAE). (2004). The Engineer of 2020: Visions of Engineering in the New Century. Washington: National Academies Press.

Okudan, G. E., \& Rzasa, S. E. (2006). A Project-Based Approach to Entrepreneurial Leadership Education. Technovation, 26, 195-210. http://dx.doi.org/10.1016/j.technovation.2004.10.012

Omoniyi, M. B. I., \& Osakinle, E. O. (2011). Unemployed Graduates' Mental Health and the Place of Entrepreneurship Education in Achieving Nigeria's Vision 20: 2020. Literacy Information and Computer Education Journal, 2(3), 470-476.

Onstenk, J. (2003). Entrepreneurship and Vocational Education. European Educational Research Journal, 2, 74-89. http://dx.doi.org/10.2304/eerj.2003.2.1.12

Owusu-Ansah, W., \& Poku, K. (2012). Entrepreneurship Education, a Panacea to Graduate Unemployment in Ghana? International Journal of Humanities and Social Science, 2(15), 211-220.

Pajares, F., \& Urdan, T. C. (Eds.). (2006). Self-Efficacy Beliefs of Adolescents. IAP.

Peters, M. (2005). Entrepreneurial Skills in Leadership and Human Resource Management Evaluated by 
Apprentices in Small Tourism Businesses. Education Training, 47(8/9), 575-591. http://dx.doi.org/10.1108/00400910510633125

Płaziak, M., \& Rachwał, T. (2014). Entrepreneurship Courses in Spatial Management Studies in Polish Universities. Procedia-Social and Behavioral Sciences, 110, 710-718. http://dx.doi.org/10.1016/j.sbspro.2013.12.915

Plumly, L. W., Marshall, L. L., Eastman, J., Iyer, Stanley, K. L., \& Boatwright, J. (2008). Developing Entrepreneurial Competencies: A Student Business. Journal of Entrepreneurship Education, 11, 17-28.

Rae, D. (2005). Entrepreneurial Learning: A Narrative-Based Conceptual Model. Journal of Small Business and Enterprise Development, 12(3), 323-335. http://dx.doi.org/10.1108/14626000510612259

Rae, D., \& Carswell, M. (2000). Using A Life-Story Approach in Researching Entrepreneurial Learning: The Development of a Conceptual Model and its Implications in the Design of Learning Experiences. Education and Training, 42(4/5), 220-228. http://dx.doi.org/10.1108/00400910010373660

Sánchez, J. C. (2011). University Training for Entrepreneurial Competencies: It's Impact on Intention of Venture Creation. International Entrepreneurship and Management Journal, 7, 239-254. http://dx.doi.org/10.1007/s11365-010-0156-x

Segal, G., Borgia, D., \& Schoenfeld, J. (2005). The Motivation to Become an Entrepreneur. International Journal of Entrepreneurial Behaviour and Research, 11(1), 42-57. http://dx.doi.org/10.1108/13552550510580834

Stoof, A. (2005). Tools for the Identification and Description of Competencies (Thesis Dissertation, Open University of Nederland).

Thompson, E. R. (2009). Individual Entrepreneurial Intent: Construct Clarification and Development of and Internationally Reliable Metric. Entrepreneurship Theory and Practice, 669-694. http://dx.doi.org/10.1111/j.1540-6520.2009.00321.x

Top, S. (2006). Girişinmcilik: KeşifSüreçi. Istanbul: Beta Yayinlari.

Top, S., Çolakoğlu, N., \& Dilek, S. (2012). Evaluating Entrepreneurship Intentions of Vocational High School Pupils Based On Self-Efficacy Concept. Procedia-Social and Behavioral Sciences, 58, 934-943. http://dx.doi.org/10.1016/j.sbspro.2012.09.1072

UGAG. (2012). Jobless Graduates Nationwide Hit Close To 100,000-UGAG. Retrieved October 3, 2013, from http:// www.modernghana.com /news /419846/1/jobless-graduates-nationwide-hit-close-to-100000-u.html

Unachukwu, G. O. (2009). Issues and challenges in the development of entrepreneurship education in Nigeria. African Research Review, 3(5).

UNESCO. (1998). Higher Education in the Twenty-First Century Vision and Action. Retrieved January 20, 2014, from http://unesdoc.unesco.org/images/0011/001166/116618m.pdf

Wickham, P. (2006). Strategic Entrepreneurship (4th ed.). London: Financial Times Prentice-Hall.

Wilson, F., Kickul, J., \& Marlino, D. (2007). Gender, Entrepreneurial Self-Efficacy, and Entrepreneurial Career Intentions: Implications for Entrepreneurship Education. Entrepreneurship Theory \& Practice, 31(3), 387-401. http://dx.doi.org/10.1111/j.1540-6520.2007.00179.x

Zhao, H., Seibert S. E., \& Hills, G. E. (2005). The Mediating Role of Self-Efficacy in the Development of

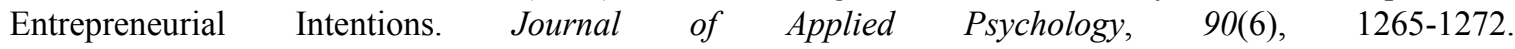
http://dx.doi.org/10.1037/0021-9010.90.6.1265

Zimmerer, T., \& Scarborough, N. (2002). The Essentials of Entrepreneurship and Small Business Management. Englewood Cliffs, NJ: Prentice-Hall.

\section{Copyrights}

Copyright for this article is retained by the author(s), with first publication rights granted to the journal.

This is an open-access article distributed under the terms and conditions of the Creative Commons Attribution license (http://creativecommons.org/licenses/by/3.0/). 